\title{
Endothelial cell death in preovulatory ovine follicles: possible implication in the biomechanics of rupture
}

\author{
W. J. Murdoch \\ Department of Animal Science, University of Wyoming, Laramie, WY 82071, USA
}

\begin{abstract}
The follicular stigma that develops near the time of ovulation in sheep is void of thecal blood vessels. It was hypothesized that programmed apoptotic death of endothelial cells is a causative factor in this phenomenon. Apoptosis is a mode of physiological cell deletion that occurs during tissue regression and remodelling; it is characterized by oligonucleosomal fragmentation and cytoplasmic shrinkage. Direct fluorescence detection of digoxigenin end-labelled genomic DNA in situ was used as a marker of endothelial apoptosis in crosssections of the preovulatory ovine follicular wall. There was an abrupt increase in reactive cells after the gonadotrophin surge that was restricted to the presumptive ovulatory site immediately juxtaposed to the ovarian surface (the basal follicular endothelia remained unaffected). Vascular collapse and extravasation of blood cells preceded follicular rupture. Localized damage to thecal blood vessels and haemorrhagic tissue ischaemia may be contributing determinants of follicular instability and ovulation.
\end{abstract}

\section{Introduction}

An elaborate vascular wreath is a characteristic feature of the theca interna of mature ovarian follicles; nutrients and hormones are thereby supplied to the inward (avascular) granulosa layer and outlying contiguous tissues. Selection and preferential growth of a preovulatory follicle is dependent on a functional microcirculatory network (Hirshfield, 1991).

The integrity of follicular microvessels is apparently compromised during the ovulatory process in some mammals. In sheep, a translucent stigma forms at the ovarian apical site of impending follicular rupture. This region is characterized by an absence of thecal blood vessels and tissue degeneration (Cavender and Murdoch, 1988; Murdoch and McCormick, 1992).

Alterations in tissue morphology are often associated with a programmed process of active physiological cell death or apoptosis. Early-stage apoptosis is distinguished by endonuclease activation, chromatin degradation and nuclear condensation. Apoptotic cells shrink and lose contact with their neighbours. Residual bodies are typically resorbed by adjacent epithelial cells or resident macrophages. Cells undergoing apoptosis may completely disappear within a few hours (Ellis et al., 1991; Fesus et al., 1991; Compton, 1992; Schwartzman and Cidlowski, 1993; Wyllie, 1993; Barr and Tomei, 1994). Programmed death of thecal endothelial cells may be responsible for the distinctive vascular reaction of preovulatory follicles.

Alterations in nuclear DNA fragmentation among thecal endothelial cells of periovulatory ovine follicles in situ were related to consequent changes in vascular morphology. Immunostaining of apoptotic cells is a very sensitive technique to monitor specific biological reactions that might otherwise be undetectable by standard DNA ladder assays of entire tissues.

Received 7 March 1995.

The method used in the present study detects apoptotic cells with a > tenfold higher sensitivity than nonspecific DNA degradation associated with necrotic cells (Gorczyca et al., 1993).

\section{Materials and Methods}

\section{Animals and treatments}

Mature western-range ewes were penned daily with vasectomized rams and observed for behavioural oestrus. Day 0 was considered the first day of oestrus. On day 14 of the oestrous cycle, animals were injected i.m. with $10 \mathrm{mg}$ prostaglandin (PG) $\mathrm{F}_{2 \alpha}$ (Upjohn Co., Kalamazoo, MI) and $36 \mathrm{~h}$ later, with $5 \mu \mathrm{g}$ Des-(D-Ala $\left.{ }^{6}\right)-\mathrm{Gly}^{10}$ gonadotrophin-releasing hormone ethylamide (GnRH; Sigma Chemical Co., St Louis, MO). These treatments synchronize the timing of luteal regression and the onset of the preovulatory surge of gonadotrophins. The largest follicle in the pair of ovaries consistently ovulates approximately $24 \mathrm{~h}$ after administration of GnRH (Roberts et al., 1985).

Midventral abdominal laparotomies were performed using aseptic technique under intravenous sodium thiopental anaesthesia. Ovaries with the dominant follicle were surgically removed at $0,8,16$ and $24 \mathrm{~h}$ after $\mathrm{GnRH}$ administration. Six animals were included in each group. A block of ovarian tissue containing the follicle of interest was excised using a singleedged razor blade and fixed by immediate immersion in $10 \%$ $(\mathrm{v} / \mathrm{v})$ neutral buffered formalin. After $4 \mathrm{~h}$, follicles were cut into apical and basal components and tissues were placed in fresh fixative for an additional $44 \mathrm{~h}$. Tissues were washed in PBS, dehydrated in a graded series of ethanol, cleared and infiltrated with paraffin wax. Embedded tissues were serially sectioned at 3-5 $\mu \mathrm{m}$. Sections were deparaffinized, rehydrated and processed for immunostaining of apoptotic endothelial cells or stained with azure blue and subjected to morphometric analyses of thecal vascularity. 


\section{DNA fragmentation analysis in situ}

Apoptotic cells were detected using an Oncor (Gaithersburg, MD) S7110 ApopTag kit, according to the instructions of the manufacturer. Briefly, exposed 3'-OH ends of DNA fragments were labelled with digoxigenin-11-d uridine triphosphate by terminal deoxynucleotidyl transferase (TdT) catalysis. Incorporated nucleotide heteropolymers were localized with antidigoxigenin Fab-fluorescein isothiocyanate. Sections were lightly counterstained in propidium iodide, dehydrated, and a coverslip was applied. Conjugate or TdT was omitted in negative control reactions. A minimum of twelve randomly selected thecal areas from sections of each tissue sample were photographed (Ektachrome $400 \mathrm{HC} ; 40 \mathrm{~s}$ exposure) at $\times 400$ under an Olympus $\mathrm{BH}-2$ microscope equipped with a reflected light fluorescence attachment. Endothelial cells with reactive (that is, intensely stained) nuclei were counted.

\section{Vascular morphometry}

Images of azure-stained tissue sections representing thecal blood vessels were projected at $\times 500$ onto a sensor pad coupled to a data analyser (Ladd Research Industries, Burlington, VT). The perimeters of lumina of individual capillaries and venules were traced and the cumulative area occupied by vascular space was computed as a percentage of total area represented by theca interna. Numbers of blood vessels $(\times 400)$ and extravascular thecal blood cells $(\times 1000)$ were counted directly under an Olympus Vanox light microscope. A minimum of eight different apical and basal fields were quantified for each variable.

\section{Statistical analyses}

Subsample data for each animal were averaged. Mean contrasts due to time of ovariectomy were made by one-way analysis of variance and protected least significant difference. Paired means (apex versus base) within time were compared by Student's $t$ test. $P$ values $<0.05$ were considered significant.

\section{Results}

At $8 \mathrm{~h}$ and $16 \mathrm{~h}$ there was evidence of preovulatory follicular swelling (antral fluid accumulation), but not of imminent rupture. A rupture point $(n=2)$ or a definitive avascular ovulatory stigma $(n=4)$ was present on follicles collected at $24 \mathrm{~h}$ after administration of GnRH. Disrupted blood vessels were evident along the periphery of stigmata.

A precipitous increase in incidence of DNA fragmentation was detected among thecal endothelial cells (Fig. 1) associated with the follicular apex at $16 \mathrm{~h}$; a corresponding change was not observed in endothelia of the basal follicular wall (Fig. 2). Intact microvessels were not seen in most cases at the follicular apex at $24 \mathrm{~h}$; and with the exception of a few isolated instances, apoptotic endothelial cells were not detected in these specimens.

The percentage area of theca interna occupied by blood vessels increased within $8 \mathrm{~h}$ after induction of the preovulatory gonadotrophin surge (Fig. 3). This was an apparent corollary of acute vasodilation (Fig. 4); there was not a concomitant increase in numbers of blood vessels (Fig. 3). Vascular param-

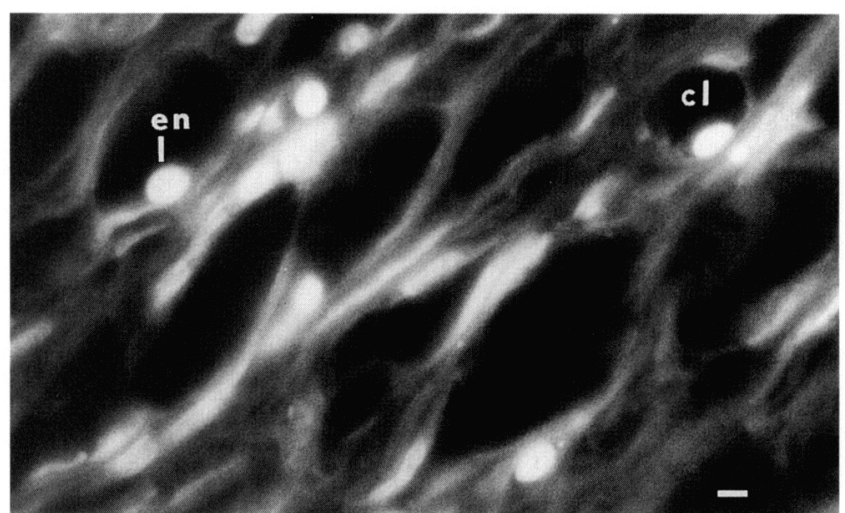

Fig. 1. Immunostaining of ovine thecal endothelium for DNA fragmentation. cl: capillary lumen; en: endothelial cell nucleus. Scale bar represents $2 \mu \mathrm{m}$.

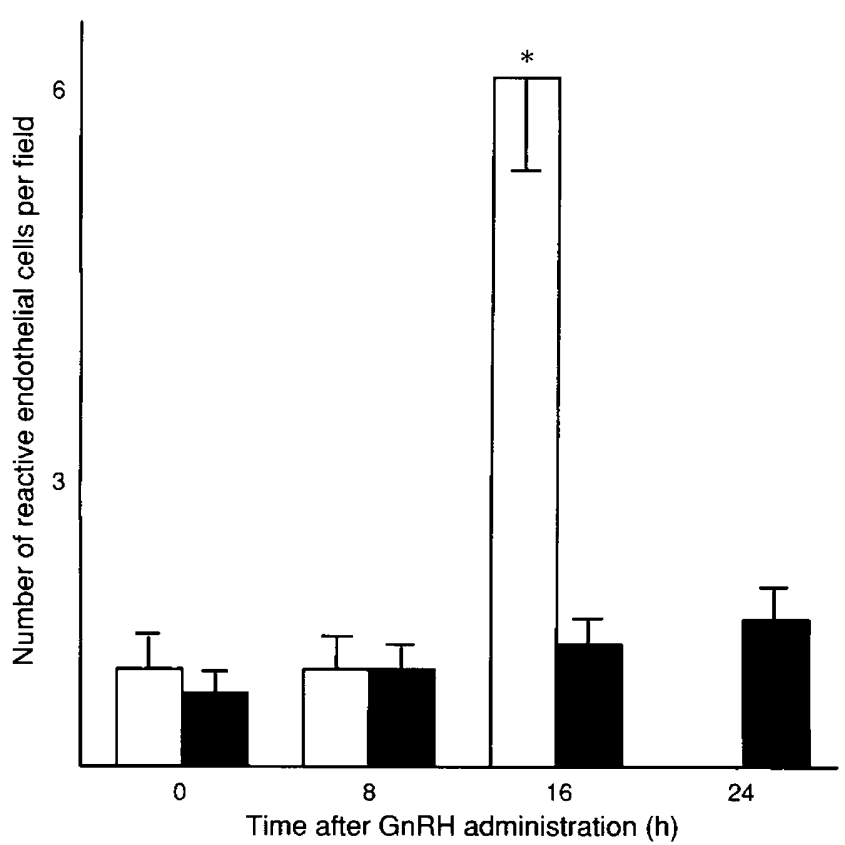

Fig. 2. Periovulatory alterations in labelling of fragmented nuclear DNA (apoptosis) within ( $\square$ ) apical and ( $\square$ ) basal ovine thecal endothelial cells. Means \pm SEM are plotted. *Significantly different response in comparison to all other values $(P<0.01)$.

eters decreased thereafter. Temporal differences between apex and base were not exhibited until $24 \mathrm{~h}$ (Fig. 3).

Blood cells were routinely found outside the vascular compartment at $24 \mathrm{~h}$ only (Fig. 5). There was a marked contrast $(P<0.01)$ between base and apex in the magnitude of this response $(6.0 \pm 2.1$ versus $23.8 \pm 3.2$ cells per field, respectively; counts on apical tissues were made from unruptured follicles only).

\section{Discussion}

The early pattern of vascular response (hyperaemia) observed in this study is indicative of the preovulatory follicular inflammatory-like reactions described by Espey (1980) and Murdoch et al. (1983). The novel aspect of this contribution is the striking contrast made between the follicular apex and base Downloaded from Bioscientifica.com at 04/26/2023 03:46:36AM 

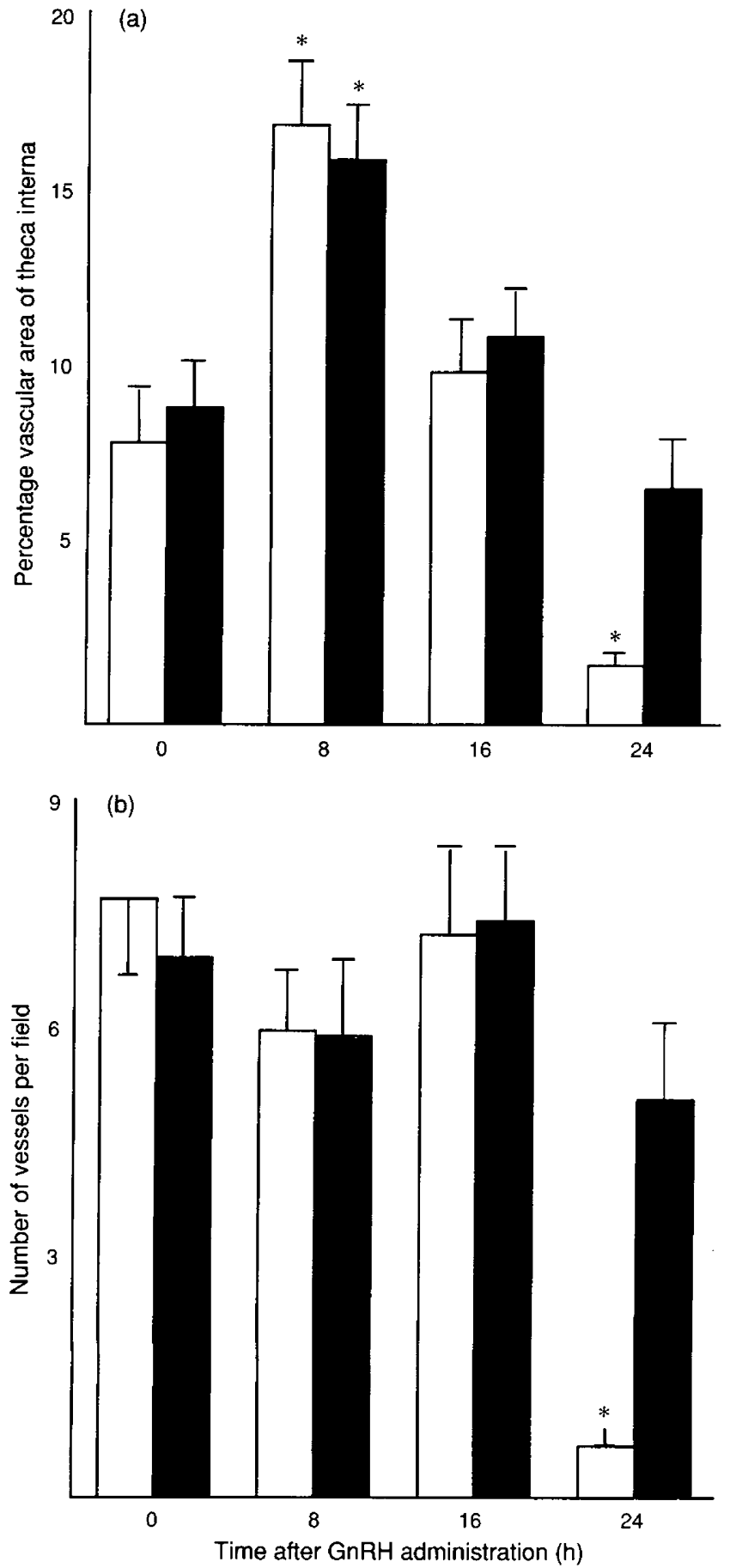

Fig. 3. Temporal alterations in ovine ( $\square$ ) apical and ( $\boldsymbol{Q}$ ) basal thecal (a) vascular space and (b) blood vessels throughout the periovulatory period. *Significantly different from $0 \mathrm{~h}$ value $(P<0.05)$ or paired mean value $(P<0.01)$

with respect to endothelial cell apoptosis, and the ensuing demise in vascular integrity. It would seem that discrete interactions occur between the ovarian surface and dominant follicle as a prelude to (contained) endothelial cell death and vascular injury. This implies that an apoptotic factor is liberated by the ovarian surface epithelium or tunica albuginea as a consequence of follicular contact. It is unlikely that the apical
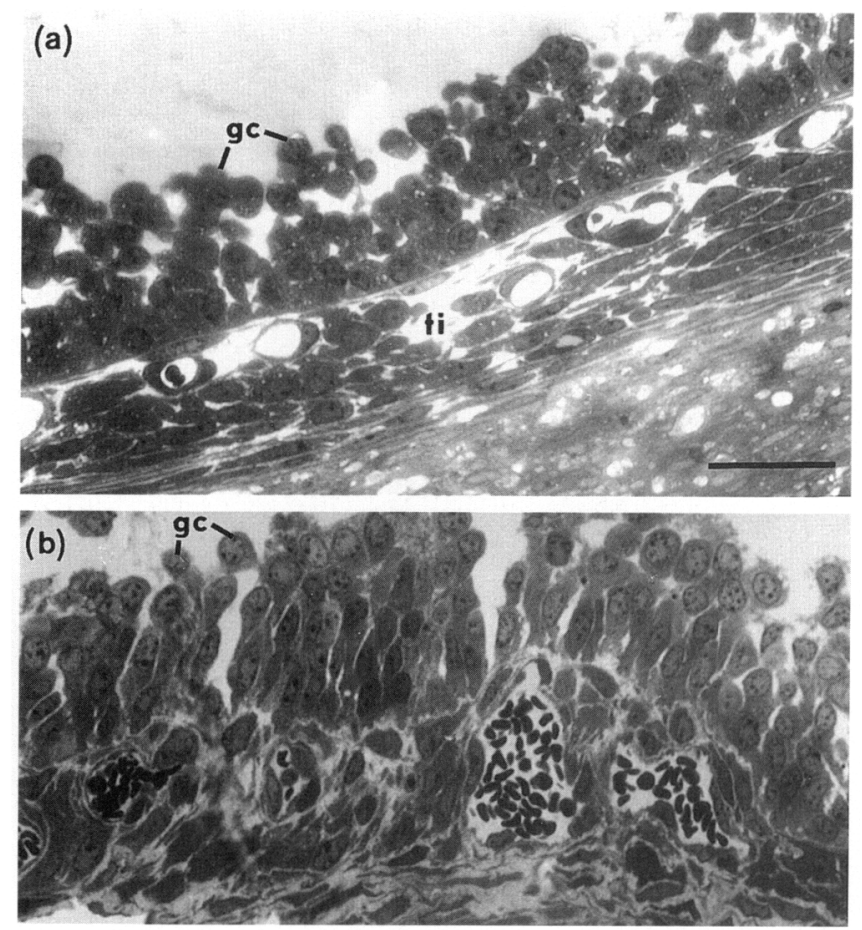

Fig. 4. Representative photomicrographs of ovine thecal crosssections at (a) $\mathrm{Oh}$ and (b) $8 \mathrm{~h}$. gc: granulosa cells; ti: theca interna. Note the thecal hyperaemic response after injection of GnRH. Scale bar represents $25 \mu \mathrm{m}$.

target is restricted to the endothelium; cellular dispersion, pyknosis, and programmed death occurred on the surface of sheep ovaries and in granulosa epithelia before ovulation (Murdoch, 1988, 1994, 1995). Interstitial phagocytes presumably remove cellular debris (Murdoch and McCormick, 1991).

Several biochemical mediators have been implicated in the induction of apoptosis (Schwartzman and Cidlowski, 1993). One substance of particular interest as pertains to the findings of this study is tumour necrosis factor $\alpha$ (TNF- $\alpha$ ) (Larrick and Wright, 1990). The hallmark of regression of experimental tumours following injection of TNF- $\alpha$ is destruction of microvessels leading to haemorrhagic necrosis. Thus, it appears that selective vascular damage deprives tumour cells of oxygen and required nutrients. Tumour necrosis factor $\alpha$ and interleukin I (a cytokine with similar biological properties to TNF) have been implicated in periovulatory ovarian processes (Ben-Rafael and Orvieto, 1992; Simon et al., 1994).

Prostaglandins are also candidate intrafollicular agents of apoptosis. Prostaglandin $\mathrm{E}_{2}$ was a potent apoptotic stimulus in primary cultures of sheep ovarian surface epithelium (Ackerman and Murdoch, 1993). It is well known that inhibition of follicular prostaglandin biosynthesis blocks ovulation in mammals (Murdoch ef al., 1993). Treatment of sheep with indomethacin during the preovulatory period negated granulosa cell-cell dissociations, ovarian surface epithelial dissipation, and formation of ovulatory stigmata (Murdoch and Myers, 1983; Murdoch, 1988, 1994; Murdoch and Cavender, 1989).

A lack of blood flow into the stigma of follicles may potentiate localized apoptosis. Depletion of serum (e.g. 

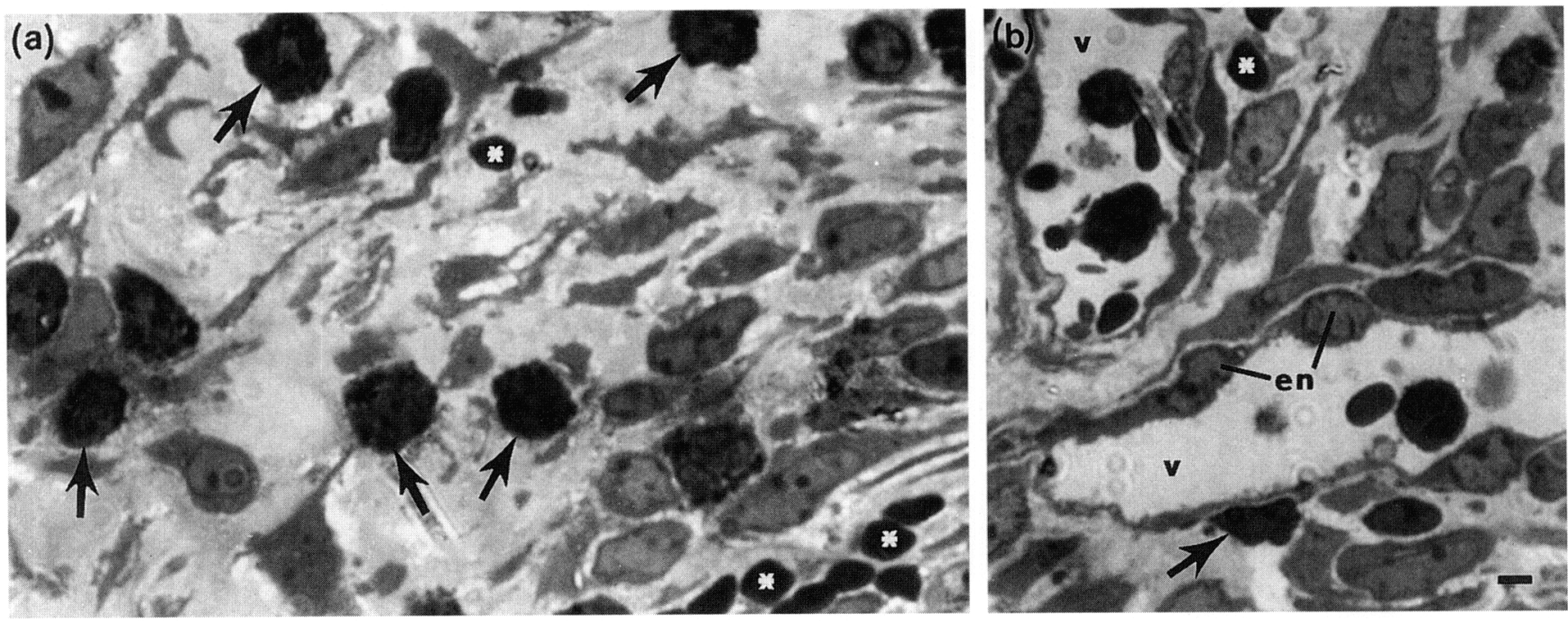

Fig. 5. High-power photomicrographs of (a) apical and (b) basal theca interna at $24 \mathrm{~h}$. There is a lack of definable blood vessels and numerous extravasated erythrocytes (*) and leucocytes (arrows) in the apical specimen. In contrast, venules (v) can be seen in the basal follicular wall. en: endothelial cell nuclei. Dissolution of the thecal connective tissue matrix is evident in both cases. Scale bar represents $3 \mu \mathrm{m}$.

growth) factors is evidently an initiating determinant in the death of oxygen-deprived myocardiocytes (Barr and Tomei, 1994). According to this scenario, cells are primed to die upon removal of an apoptosis-inhibiting element.

An involvement of apoptosis in follicular rupture does not necessarily preclude a role for lytic cellular death or other auxiliary mechanisms (for example collagenolysis). In contrast to apoptosis, necrosis is a nongenomic process usually caused by physical insult. It is exemplified by loss of plasma membrane integrity and inflammation (Schwartzman and Cidlowski, 1993). Ischaemia would presumably lead to secondary tissue necrosis, which might thereby contribute to follicular weakening.

A universal role for apoptosis in a diversity of ovarian functions is emerging. Programmed cell death has also been implicated in the mechanisms of follicular atresia (Hsueh et al., 1994) and luteal regression (Juengel et al., 1993; Dharmarajan et al., 1994).

\section{References}

Ackerman RC and Murdoch WJ (1993) Prostaglandin-induced apoptosis of ovarian surface epithelial cells Prostaglandins 45 473-483

Barr PJ and Tomei LD (1994) Apoptosis and its role in human disease Biotechnology 12 487-493

Ben-Rafael Z and Orvieto R (1992) Cytokines - involvement in reproduction Fertility and Sterility 58 1093-1099

Cavender JL and Murdoch WJ (1988) Morphological studies of the microcirculatory system of periovulatory ovine follicles Biology of Reproduction $\mathbf{3 9}$ 989997

Compton MM (1992) A biochemical hallmark of apoptosis: internucleosomal degradation of the genome Cancer and Metastasis Reviews 11 105-119

Dharmarajan AM, Goodman SB, Tilly KI and Tilly JL (1994) Apoptosis during functional corpus luteum regression: evidence of a role for chorionic gonadotropin in promoting luteal cell survival Endocrine Journal 2 295-303

Ellis RE, Yuan J and Horvitz HR (1991) Mechanisms and functions of cell death Annual Revieze of Cell Biology $7663-698$

Espey LL (1980) Ovulation as an inflammatory reaction - a hypothesis Biology of Reproduction 22 73-106
Fesus L, Davies PJA and Piacentini M (1991) Apoptosis: molecular mechanisms in programmed cell death European Journal of Cell Biology 56 170-177

Gorczyca W, Bigman K, Mittelman A, Ahmed T, Gong J, Melamed MR and Darzynkiewicz Z (1993) Induction of DNA strand breaks associated with apoptosis during treatment of leukemias Leukemia 7 659-670

Hirshfield AN (1991) Development of follicles in the mammalian ovary International Review of Cytology 124 43-10I

Hsueh AJW, Billig H and Tsafriri A (1994) Ovarian follicle atresia: a hormonally controlled apoptotic process Endocrine Reviews 15 707-724

Juengel JL, Garverick HA, Johnson AL, Youngquist RS and Smith MF (1993) Apoptosis during luteal regression in cattle Endocrinoloyy 132 249-254

Larrick JW and Wright SC (1990) Cytotoxic mechanism of tumor necrosis factor a FASEB Journal 4 3215-3223

Murdoch WJ (1988) Disruption of cellular associations within the granulosal compartment of periovulatory ovine follicles: relationship to maturation of the oocyte and regulation by prostaglandins Cell and Tissue Research $\mathbf{2 5 2}$ 459-462

Murdoch WJ (1994) Ovarian surface epithelium during ovulatory and anovulatory ovine estrous cycles Anatomical Record 240 322-326

Murdoch WJ (1995) Programmed cell death in preovulatory ovine follicles Biology of Reproduction 53 8-12

Murdoch WJ and Cavender JL (1989) Effect of indomethacin on the vascular architecture of preovulatory ovine follicles: possible implication in the luteinized unruptured follicle syndrome Fertility and Sterility 51 153-155

Murdoch WJ and McCormick RJ (1991) Leukocyte chemoattraction and periovulatory follicular processes. In Signaling Mechanisms and Gene Expression in the Ovary pp 153-162 Ed. G Gibori. Springer-Verlag, New York

Murdoch WJ and McCormick RJ (1992) Enhanced degradation of collagen within apical versus basal wall of ovulatory ovine follicles American journal of Physiology 263 E221-E225

Murdoch WJ and Myers DA (1983) Effect of treatment of estrous ewes with indomethacin on the distribution of ovarian blood to the periovulatory follicle Biology of Reproduction 29 1229-1232

Murdoch WJ, Nix KJ and Dunn TG (1983) Dynamics of ovarian blood supply to periovulatory follicles of the ewe Biology of Reproduction 28 1001-1006

Murdoch WJ, Hansen TR and McPherson LA (1993) Role of eicosanoids in vertebrate ovulation Prostaglandins 46 85-115

Roberts AJ, Dunn TG and Murdoch WJ (1985) Induction of ovulation in proestrous ewes: identification of the ovulatory follicle and functional status of the corpus luteum Domestic Animal Endocrinology 2 207-210

Schwartzman RA and Cidlowski JA (1993) Apoptosis: the biochemistry and molecular biology of programmed cell death Endocrine Revievos 14 133-151

Simon C, Tsafriri A, Chun SY, Piquette GN, Dang W and Polan ML (1994) Interleukin 1 receptor antagonist suppresses human chorionic gonadotropininduced ovulation in the rat Biology of Reproduction 51 662-667

Wyllie AH (1993) Apoptosis British Journal of Cancer 67 205-208 